\title{
Phantom Borders in Eastern Europe: A New Concept for Regional Research
}

\author{
Béatrice von Hirschhausen, Hannes Grandits, Claudia Kraft, \\ Dietmar Müller, and Thomas Serrier
}

This paper proposes the concept of phantom borders as a "creative metaphor" in order to provide new impetus to regional research, especially on eastern Europe. ${ }^{1}$ Our reflections were stimulated by the contemplation of maps that depict current election results, demographic data, the routes of railway lines, and the striking similarities between regional peculiarities and long-abolished border demarcations. Like phantoms, old territorial subdivisions seem to haunt current societies in east central and southeastern Europe.

Figure 1 shows a map of east central and southeastern Europe, indicating that the region's population and territories have been repeatedly affected by altered state borders since the nineteenth century. To date, the political map in this area seems to have been more flexible than in western Europe. This was borne out once again in the watershed years of 1989/91. In eastern Europe, new political boundaries emerged from former state or regional borders that had been abolished, especially since the Second World War. In recent decades, no other region in the world has witnessed the establishment of so many new/old independent states: Estonia, Latvia, Lithuania, Belarus, Ukraine, Czech Republic, Slovakia, Slovenia, Croatia, Serbia, Bosnia and Herzegovina, Macedonia, Montenegro, and Kosovo.

The project "Phantom Borders in Eastern Europe," established in 2010, developed out of a mutual interest in the transformation processes in central and eastern Europe. In particular, a network of historians, geographers, and cultural scientists brought together research institutions in Germany and central and southeastern Europe and set itself the goal of reflecting on spaces and

We thank the editor, Harriet L. Murav, for in-depth suggestions and the efficient handling of the manuscript, and the anonymous referees for very constructive and valuable suggestions; the usual disclaimer applies.

1. Peter Finke, "Misteln, Wälder und Frösche: Über Metaphern in der Wissenschaft," Metaphorik.de, no. 4 (2003): 45-65, 55, at https://www.metaphorik.de/sites/www.metaphorik.de/files/journal-pdf/04_2003_finke.pdf (accessed April 11, 2019). 


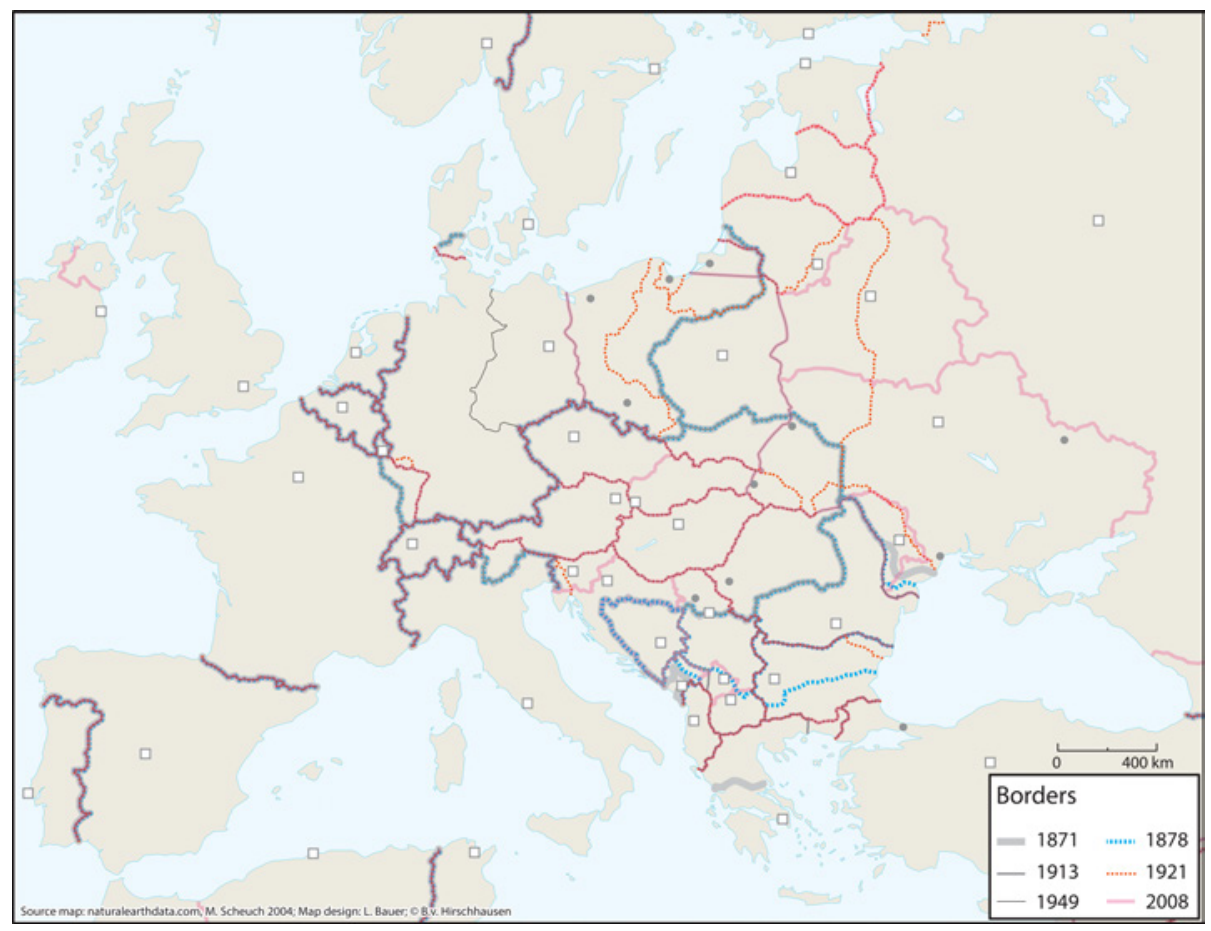

Figure 1. Palimpsest of boundaries in east central Europe.

actors during this time period in a new way. ${ }^{2}$ Within this context, research has been consistently carried out by the network's members in order to arrive at a shared understanding of the phantom borders metaphor. We chose an interdisciplinary and inductive research approach based on case studies because we felt it was imperative to use concrete empirical examples to scrutinize and test propositions associated with the phantom borders concept. ${ }^{3}$ Researchers

2. In addition to the Centre Marc Bloch in Berlin, the Chair of South-East European History at Humboldt-University in Berlin, the Centre for Modern Oriental Studies in Berlin, and the Chair of East European History at Martin Luther University in Halle-Wittenberg, several other research institutions have participated in the project in Germany (European University Viadrina Frankfurt/Oder, Siegen University, Centre for the History and Culture of East Central Europe Leipzig (GWZO), Freie Universität Berlin, Center for Historical Research of the Polish Academy of Sciences in Berlin); in central and southeastern Europe (Silesian Institute in Opole, University of Zagreb, University of Iaşi); and in other European countries (CERCEC/Paris, CETOBAC/Paris, University of Basel, Switzerland).

3. In the meantime, the members of the research network have published first results in the series "Phantomgrenzen im östlichen Europa"; see in particular Béatrice von Hirschhausen, Hannes Grandits, Claudia Kraft, Dietmar Müller, and Thomas Serrier, Phantomgrenzen-Räume und Akteure in der Zeit neu denken (Göttingen, 2015); Rita Aldenhoff-Hübinger, Catherine Gousseff and Thomas Serrier, eds., Europa vertikal. Zur Ost-West-Gliederung im 19. und 20. Jahrhundert (Göttingen, 2016); Michael G. Esch and Béatrice von Hirschhausen, eds., Wahrnehmen, Erfahren, Gestalten: Phantomgrenzen und soziale Raumproduktion (Göttingen, 2017). See also several articles translated into English as part of the thematic issue edited by Béatrice von Hirschhausen, "Phantom Borders," 
from the project have contributed significantly to the development of the phantom-borders concept by applying it to specific local terrain.

\section{Approaches: Concept and Heuristic Metaphor}

By phantom borders, we understand earlier, mostly political demarcations or territorial divisions that structure space despite their subsequent institutional abolishment. In many cases, historical spaces or their fragmentation continue to have an effect or even occasionally reemerge, such as in the cases of the Habsburg Empire, the Ottoman Empire, the division of Germany, and the partitions of Poland. This working definition allows us to examine concrete and recent examples of the (re)appearance of historical phantom spaces. Despite spatial restructuring, they continue to shape social practices. Residual phenomena can be found, for example, in architecture and rural settlement patterns; they are also displayed in statistics or maps on voting behavior or other social practices. On the basis of these empirical examples, we will inductively construct a more ambitious theoretical concept, put forward in the last section of this paper.

One telling example of phantom borders can be found in the map of the 2015 presidential elections in Poland. Figure 2 shows the second round of voting in this election. The strong regional differences in the results in eastern and western Poland disclose the effects of both the border demarcations in the aftermath of the First World War and the boundaries of the partition period from 1795 to $1918 .^{4}$

Our focus, however, lies less on the borders themselves than the spaces that have been created by socialization processes within the former territories. Border controls, fences, walls, and border posts with barriers can be abolished with a single political decision, or they can lose their original meaning. At the same time, the structures and institutions created by political actors may change very little, or not at all, over longer periods of time. Thus, infrastructure networks or the land allocations stemming from specific agricultural policies, as well as legal cultures and traditional norms, have created long-lasting territorial structures. The spaces and institutions created in this way can endure well beyond the lifetime of their originating states.

The term phantom borders is thus metaphorical: just as so-called phantom pains are felt in an amputated part of the human body, phantom borders are tangible traces (sometimes fleeting, sometimes more permanent) of nowdefunct political entities and their external borders. The term phantom borders can be used as a heuristic tool to facilitate reflection on regional differences, which goes beyond the traditional narratives of regional history. In this way, we are particularly interested in the construction and reproduction processes of regional differences. Our work is distinguished from historiography, which

in L'Espace géographique 46, no. 2 (2017): 97-173, at https://www.cairn-int.info/list_ articles_fulltext.php?ID_REVUE=E_EG (accessed May 3, 2019).

4. For an analysis of the election results in Poland, see the article by Tomasz Zarycki, "The Electoral Geography of Poland: Between Stable Spatial Structures and Their Changing Interpretations,” Erdkunde: Archive for Scientific Geography 69, no. 2 (2015): 107-24. 


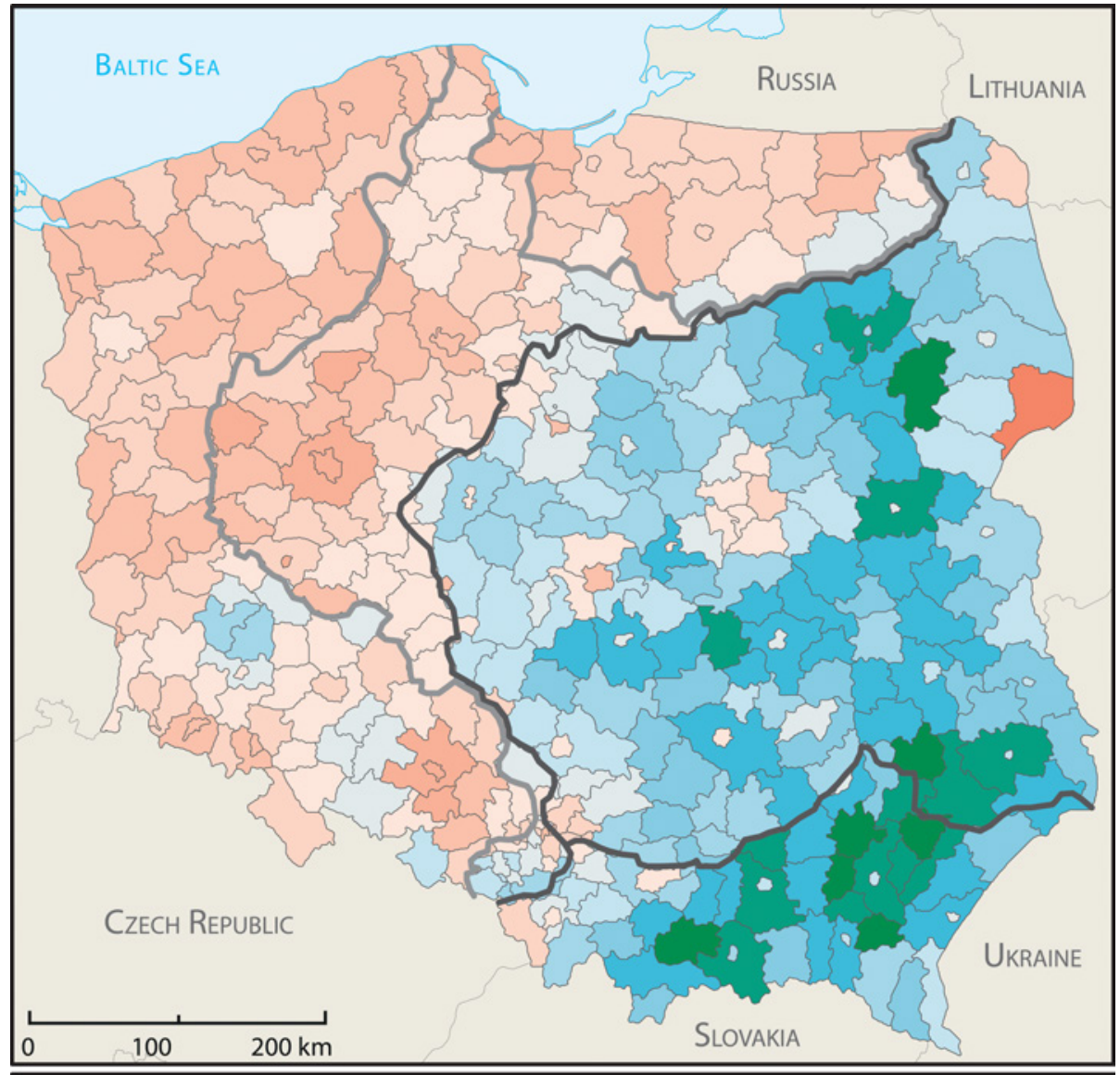

Election results by administrative districts

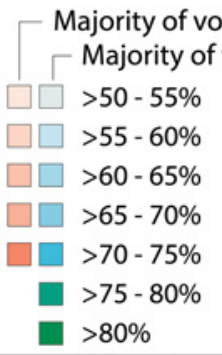

- Border until 1918

- Border 1921-1939/1945

Figure 2. Electoral map for the second round in the 2015 Polish presidential election.

attributes specific characteristics to a region, determines their borders to be "natural" and, consequently, contributes to a reification of regions as fixed cultural spaces. A study that foregrounds phantom borders and phantom spaces positions itself against linear perspectives that are solely focused on the assumed region in question. In the study of phantom borders and phantom spaces, the primary question is how and why varied social, historical, 
and imagined heritages mutually influence each other. Here, they not only can combine to create something new, but also persist over a more or less extended period of time. We underscore the ephemeral and non-deterministic nature of the examined regions: their "phantom-like" nature.

It is important to emphasize that the term of phantom borders is not intended to rationalize imperial nostalgia through scholarly means or, for that matter, to justify irredentist goals. The concept should not be misunderstood as an attempt to (re)construct social or historical causalities in order to impart certain mental maps a physical or social basis. Rather, the study of phantom borders aims to arrive at a situational understanding of how the characteristics of a region establish and reproduce themselves, the circumstances under which they survive specific historical periods, and why they disappear. In focusing on phantom borders and spaces it will be possible to present in detail the intrinsic value of historic areas, without, however, essentializing them or reifying their physical borders. Therefore, the concern is not with describing allegedly immutable spaces. Our point of departure is instead the recognition that ideas of space are always relational. We thus put a spotlight on the social and historical processes shaping space.

\section{The Scientific Challenge}

In historiography, the perception of historically-determined regional differences has been examined for many years from the perspective of a structuralist paradigm. Here, the primary interest is to trace in the longue durée the historical development of social, cultural, or economic structures that are considered specific to a region. The most important touchstone for this approach is the French Annales school of historical criticism. Fernand Braudel's book on the Mediterranean is considered a seminal work. ${ }^{5}$ In it, he endeavors to write a "deep" history (histoire profonde) inspired by the social sciences. He stresses the importance of a number of structural factors, including: "geographical facts ... ; then cultural facts; ethnic facts; social-structure facts; economic facts, and, finally, political facts." ${ }^{\circ}$ From this perspective, the regions emerge out of a longue durée of structures that ensure their permanence. ${ }^{7}$ By writing a géohistoire for the specific region, which imparts a spatial dimension to the historical perspective, these structures can be made tangible. ${ }^{8}$

Many classic works on the historical regions of eastern Europe draw on this theoretical framework. The work of the Polish-American medieval and modern historian Oskar Halecki is paradigmatic. He has traced up to the present day the impact of the historic dividing line of the east-west schism

5. Fernand Braudel, The Mediterranean and the Mediterranean World in the Age of Philip II, trans. Syan Reynolds, 2 vols. (New York, 1972-73).

6. Fernand Braudel, Les ambitions de l'histoire, eds. Roselyne De Ayala and Paule Braudel (Paris, 1997), 58.

7. Fernand Braudel, “Histoire et Sciences Sociales: La longue durée,” Annales. Économies, Sociétés, Civilisations 13, no. 4 (1958): 725-53.

8. Matthias Middell, "Der Spatial Turn und das Interesse an der Globalisierung in der Geschichtswissenschaft,” in Jörg Döring and Tristan Thielman, eds., Spatial Turn. Das Raumparadigma in den Kultur- und Sozialwissenschaften (Bielefeld, 2008): 103-24. 
between the Western Church of east-central Europe and the Eastern Church of eastern Europe. Also noteworthy is the work of the Hungarian medievalist Jenő Szücs on the distinction between western Europe, central Europe, and eastern Europe. As Fernand Braudel writes in the introduction to Szücs' book, it shows how "societal structures [lie] behind the historical events that have a decisive impact over an extended period of time."

In recent years, two different camps have questioned this structuralist approach to explaining the emergence and continuation of regional entities. On the one hand, microhistorical approaches deny the deterministic effect of structures and instead stress the actors' scope for action and their ability to act. On the other hand, poststructuralist approaches, drawing on postcolonial studies, criticize the west European-centered perspective of many classic works and take issue with attempts to divide Europe into clearly-defined regions. Both points of view will be elaborated in more detail below, making it possible to propose a way forward for area studies that is more constructive and methodologically reflective.

\section{Critique of Determinism: Space-Time Constellations without Actors}

We will begin by highlighting the structuralist approach and its critique from a microhistorical perspective. Braudel asserts that the actors are affected by the existing (geographical) structures and, as a consequence, are limited in their ability to act. At the same time, he rejects a purely deterministic view and instead seeks to identify a tradeoff in the field of tension between physical space and social existence. ${ }^{10}$ But how can this balancing act between structure and action be productively dealt with in research practice? How can the continuing influence of structural factors be explained and conceptualized without resorting to (more or less hidden) deterministic explanations? Finally, how can such phenomena be described without essentializing them? The pitfalls of such a line of questioning can be demonstrated on the basis of the following example.

A work frequently cited in connection with the persistence of a historical heritage is Robert D. Putnam's Making Democracy Work: Civic Traditions in Modern Italy. ${ }^{11}$ The author compares the administrative practices and the institutional capacity of regional administrations in northern and southern Italy, which were reorganized in the 1970s. Putnam paints a picture of a divided Italy. The north is represented as a region with efficient bureaucracies and active civic communities, whose social relationships are based on trust, reciprocity, and the equal treatment of citizens. By contrast, the south of the country is purportedly a region with weak civil societies, where good relations with key players in the bureaucratic system are of special importance and clientelism is widespread. Putnam then establishes a connection between the map of civicism of the current local communities and the map of

9. Jenő Szücs, Die drei historischen Regionen Europas, introduction by Fernand Braudel (Frankfurt/Main, 1990); Oskar Halecki, The Limits and Divisions of European History (London, 1950).

10. See Braudel, Les ambitions de l'histoire, 84-86.

11. Robert D. Putnam, Robert Leonardi, and Raffaella Y. Nanetti, Making Democracy Work: Civic Traditions in Modern Italy (Princeton, 1993). 
political regimes in the Middle Ages to explain the underlying cause for these differences. The upshot of his analysis is that there is historical evidence for a linear connection between the political geography of Italy in the fourteenth century and that of the active civil societies in the 1970s and 1980s. Putnam establishes causality from a presumed homology-a kind of evolutionarilydetermined correspondence between the two political configurations. It thus appears as though the phantom of the phenomenon represented by the map from the fourteenth century can be recognized in the map of the structures of civil societies from the end of the twentieth century. ${ }^{12}$

The work of Robert Putnam is representative in its focus on the continuity of regional differences. It relies on an essentialization of certain factors-specifically, the political structures of the fourteenth century-as the seminal moment of difference. These structures are conceived as autonomous components that arise at a particular time in history and exert influence from that point forward. The impact of the respective ur-moment in history, to which Putnam ascribes various regional developments, suggests that these formative ur-structures are neither significantly affected by historical events and caesurae, nor by the decisions of actors. Understandably, Putnam's work has triggered fierce criticism. ${ }^{13}$ It is nonetheless an example of a prominent theoretical approach that gives primacy to structures while marginalizing the role of individual agency.

A range of disciplines have increasingly called similar viewpoints into question since the 1980s. In this context, a series of important debates have emerged such as the dispute between Alltagsgeschichte and social history in Germany, ${ }^{14}$ or the controversies ignited in Italy by microstoria ${ }^{15}$ or in France by the tournant critique of the Annales school. ${ }^{16}$ A related development can be observed in historical demography. ${ }^{17}$ All these debates were driven by the

12. See Putnam, Leonardi, and Nanetti, Making Democracy Work, 133.

13. For a critique of Robert Putnam, see Margaret Levi, "Social and Unsocial Capital: A Review Essay of Robert Putnam's Making Democracy Work," Politics \& Society 24, no. 1 (1996): 45-55; Sidney Tarrow, "Making Social Science Work Across Space and Time: A Critical Reflection on Robert Putnam's Making Democracy Work," The American Political Science Review 90, no. 2 (Jun 1996): 389-97; Hervé Rayner, "Le point de vue aérien de Robert Putnam. À propos de Making Democracy Work," Politix: Revue des sciences sociales du politique 11, no. 42 (1998): 179-204.

14. Alf Lüdtke, Alltagsgeschichte: Zur Rekonstruktion historischer Erfahrungen und Lebensweisen (Frankfurt/Main, 1989); Winfried Schulze, ed., Sozialgeschichte, Alltagsgeschichte, Mikro-Historie: Eine Diskussion (Göttingen, 1994).

15. Carlo Ginzburg, "Microstoria: Due o tre cose che so di lei," Quaderni Storici 29, no. 86 (2) (August 1994): 511-39; Jacques Revel, Jeux d'échelles. La micro-analyse à l'expérience (Paris, 1996).

16. Collectif, "Histoire et sciences sociales. Un tournant critique?," Annales. Économies, Sociétés, Civilisations 43, no. 2 (1988): 291-93; Bernard Lepetit, ed., Les formes de l'expérience: Une autre histoire sociale (Paris, 1995); Bernard Lepetit, "L'histoire prend-telle les acteurs au sérieux?,” EspaceTemps 59-61 (1995): 112-22.

17. Pier Paolo Viazzo and Katherine A. Lynch, "Anthropology, Family History, and the Concept of Strategy," International Review of Social History 47, no. 3 (December 2002): 42352; Theo Engelen and Arthur P. Wolf, eds., Marriage and the Family in Eurasia: Perspectives on the Hajnal Hypothesis (Amsterdam, 2005); Sebastian Klüsener, Mikołaj Szoltysek, and Joshua R. Goldstein, "Towards an Integrated Understanding of Demographic Change and its Spatio-Temporal Dimensions: Concepts, Data Needs, and Case Studies,” Die Erde: Zeitschrift der Gesellschaft für Erdkunde zu Berlin 143, no. 1-2 (January 2012): 75-104. 
search for a new paradigm-one that puts the actors at the center, contextualizes their actions, and offers explanations that address the sequence and the internal dynamics of the actions themselves. Hence, the respective situational logic is placed in the foreground with more attention being paid to the agency of the subjects themselves. ${ }^{18}$

The interest in historical agency also grew in the field of area studies, albeit with a certain time lag that was at least partly due to the discipline's inherent structuralist imprint. But scholars embraced the challenge of remaining area specialists, while also combining their regional expertise with innovative research perspectives. Especially from the year 2000 onward, they adapted the spatial turn to their methodological repertoire, not least to continue the scientification of east European area studies. This body of research demonstrates how integrating spatiality into historical research can inform a historiography that is sensitive to local agency without ignoring the persistence of mental maps. Approaches focusing on subnational spatial units such as regions or cities proved to be particularly productive. ${ }^{19}$ Studies concerned with a "classical" subject in east European studies like nationalism have also increasingly taken into account the relevance of spatial constructions for processes of nationalization in its different guises. ${ }^{20}$ Last but not least, recent historiography has reflected on practices-both cognitive and infrastructural-to “master" space in an original way. ${ }^{21}$

18. Etienne François, Die unsichtbare Grenze: Protestanten und Katholiken in Augsburg 1648-1806 (Sigmaringen, 1991); John W. Cole and Eric R. Wolf, The Hidden Frontier: Ecology and Ethnicity in an Alpine Valley (New York, 1974); Christophe Duhamelle, La frontière au village: Une identité catholique allemande au temps des Lumières (Paris, 2010); Christophe Duhamelle, "Raum, Grenzerfahrung und konfessionelle Identität im Heiligen Römischen Reich im Barockzeitalter,” in Karin Friedrich, ed., Die Erschließung des Raumes: Konstruktion, Imagination und Darstellung von Räumen und Grenzen im Barockzeitalter (Wiesbaden, 2014): 23-45.

19. For approaches that focus on the historical impact of locality or regionality, see for instance Philipp Ther and Holm Sundhaussen, eds., Regionale Bewegungen und Regionalismen in europäischen Zwischenräumen seit der Mitte des 19. Jahrhunderts (Marburg, 2003); Beth Mitchneck, "Geography Matters: Discerning the Importance of Local Context," Slavic Review 63, no. 3 (Fall 2005): 491-516; Christophe Duhamelle, Andreas Kossert and Bernhard Struck, eds., Grenzregionen. Ein europäischer Vergleich vom 18. bis zum 20. Jahrhundert (Frankfurt/Main, 2007); Susan Smith-Peter, Imagining Russian Regions: Subnational Identity and Civil Society in Nineteenth-Century Russia (Leiden, 2018). Cities have also attracted the attention of researchers as sites of historical agency: Felix Ackermann, Palimpsest Grodno. Nationalisierung, Nivellierung und Sowjetisierung einer mitteleuropäischen Stadt, 1919-1991 (Wiesbaden, 2010); Gregor Thum, Uprooted: How Breslau Became Wroctaw during the Century of Expulsions (Princeton, 2011); and Christoph Mick, Lemberg, Lwów, L'viv, 1914-1947: Violence and Ethnicity in a Contested City (West Lafayette, 2016).

20. Jeremy King, Budweisers into Czechs and Germans: A Local History of Bohemian Politics, 1848-1948 (Princeton, 2002): Pieter M. Judson, Guardians of the Nation: Activists on the Language Frontiers of Imperial Austria (Cambridge, Mass., 2006): Marius Turda and Paul J. Weindling, eds., Blood and Homeland: Eugenics and Racial Nationalism in Central and Southeast Europe, 1900-1940 (Budapest, 2007): Tara Zahra, Kidnapped Souls: National Indifference and the Battle for Children in the Bohemian Lands, 1900-1948 (Ithaca, 2008).

21. Steven Seegel, Mapping Europe's Borderlands: Russian Cartography in the Age of Empire (Chicago, 2012); Friederike Kind-Kovács, Written Here, Published There: How 


\section{Space-Power-Knowledge Constellations: The Poststructuralist Criticism}

A second form of critique of the persistence of historical regions or cultural areas involves research in which spatial concepts are discursively (re)produced and considered to be part of a specific order of knowledge. Following postcolonial studies, representatives of this poststructuralist approach criticize the constructed nature of the knowledge of specific regions and expose its role in the self-legitimation of the west. Since the 1990s, several studies have identified how Europe has described the existence of the "other" in its eastern and southern peripheries in order to position its own "civilization. ${ }^{22}$ The respective situatedness of eastern Europe, east central Europe, and southeastern Europe remains ambiguous, however. They are to some extent semi-peripheries: regions thatthough marginalized and limited-can be counted as belonging to the (west) European/North Atlantic center or strongly defined in relation to this center. This relationality is important for the localization of regions in space and time: eastern Europe is not intrinsically different, but must nevertheless assimilate to benefit from the claim of Europeanness. As a consequence, the topos of backwardness has been formalized in the description of the semi-periphery.

Purportedly, "general" scientific disciplines reduce the "peripheries" to "matters of empirical research that fleshes out a theoretical skeleton which is substantially “Europe."”23 On the one hand, this viewpoint highlights the precarious relationship of area studies to the respective "primary" disciplines. On the other, it implies that the peripheries can only be thought of in a mode of "homogenizing transition narratives" that have to emulate a predefined ideal from the center. ${ }^{24}$ In this critical perspective, eastern Europe is comparable to the regions under investigation in postcolonial studies, for it, too, is considered in terms of its dependency on a hegemonic Europe. This dependency is also reflected in the temporalizing of the relevant descriptive and analytical concepts-as, for instance, with the terms "backwardness," "transformation," and "return to Europe." East European actors have been and continue to be confronted with their imminent absorption by means of allegedly "universal" developmental paths. Besides this teleological perspective, there

Underground Literature Crossed the Iron Curtain (Budapest, 2014); Alexander Badenoch, Andreas Fickers, and Christian Henrich-Franke, eds., Airy Curtains in the European Ether: Broadcasting and the Cold War (Baden-Baden, 2013); Frithjof Benjamin Schenk, Russlands Fahrt in die Moderne: Mobilität und sozialer Raum im Eisenbahnzeitalter (Stuttgart, 2014).

22. Larry Wolff, Inventing Eastern Europe: The Map of Civilization on the Mind of the Enlightenment (Stanford, 1994); Maria Todorova, Imagining the Balkans (Oxford, 1997); Iver B. Neumann, Uses of the Other: The "East" in European Identity Formation (Manchester, 1999); see also Karl Kaser, Dagmar Gramshammer-Hohl, Robert Pichler, Christian Promitzer, and Elisabeth Vogel, eds., Europa und die Grenzen im Kopf, vol. 11 of Wieser Enzyklopädie des europäischen Ostens (Klagenfurt, 2003); Ezequiel Adamovsky, "EuroOrientalism and the Making of the Concept of Eastern Europe in France, 1810-1880," The Journal of Modern History 77, no. 3 (September 2005): 591-628; Gunther Gebhard, Oliver Geislerand, and Steffen Schröter, eds., Das Prinzip "Osten”: Geschichte und Gegenwart eines symbolischen Raums (Bielefeld, 2010).

23. Dipesh Chakrabarty, Provincializing Europe: Postcolonial Thought and Historical Difference (Princeton, 2000), 29.

24. Ibid., 32. 
is a risk of essentializing eastern Europe and insisting on its fundamental cultural "otherness."

Therefore, with regard to southeastern Europe and the Balkans, the German historian Holm Sundhaussen and the Bulgarian-American historian Maria Todorova discussed whether supporting regional research on spatial concepts can be justified. ${ }^{25}$ Ultimately, the debate could not be resolved. No historical regions are in fact stable across time and space, yet the success of such spatial constructs has, at least in part, an empirical basis. Bearing this in mind, we remained cognizant of the fact that although historians or geographers might successfully deconstruct the conception of nations or regions, the historical and current actors themselves still refer in their everyday practices to seemingly homogenous social collectivities or spaces. It is thus necessary to take into account highly influential mental maps, not only at the level of discourse but also in terms of everyday practices.

\section{The Phantom Borders Concept Beyond Determinism and Deconstructionism}

In our approach, we are skeptical of spatially-construed determinisms à la Putnam, which perpetuate spaces or regional borders by means of selected intrinsic social factors. At the same time, we argue against retreating to a deconstructivist postulate that views any analytical commitment (not least one regarding a region and its borders) as ultimately only being produced through language and discourse. We understand the concept of phantom borders as being located outside of these (explicitly and implicitly) predominant interpretative approaches. The concept not only makes it possible to place "processes of persistence" at the center of analysis, but to finally explain the "re-emergence" of (phantom) borders or their transformation, as well as the persistence of historical (or new) spatial concepts and practices. The phantom-borders concept is thus decidedly informed by a systematic view of social processes enshrined in spaces and their respective boundaries.

We assume that ideas of regional differences are manifested at various levels, interrelated, and able to mutually reinforce or weaken each other. We always understand phantom borders and spaces as simultaneously imagined (produced and passed on discursively), experienced (perceived as experience and updated in practice by the actors and scientific observers), and designed (by territorialization processes). Thus, the interaction between spatial imagination, spatial experience, and spatial design is fundamental to the concept of phantom borders.

The three levels of the phantom borders are based on the triad of space proposed by Henri Lefebvre in his 1974 published work, La production de

25. Todorova, Imagining the Balkans; Holm Sundhaussen, "Europa balcanica. Der Balkan als historischer Raum Europas," Geschichte und Gesellschaft 25, no. 4 (Oct.-Dec. 1999): 626-53; Maria Todorova, "Der Balkan als Analysekategorie: Grenzen, Raum, Zeit," Geschichte und Gesellschaft 28, no. 3 (Jul.-Sep. 2002): 470-92; Holm Sundhaussen, "Der Balkan: Ein Plädoyer für Differenz,” Geschichte und Gesellschaft 29, no. 4 (Oct.-Dec. 2003): 608-24. 
l'espace. ${ }^{26}$ Lefebvre comprehends space as a unity that is produced by lived space (espace vécu), perceived space (espace perçu), and conceived space (espace conçu). The first, Espace vécu, is defined as "lived space mediated by images and symbols." 27 It is the research focus of ethnologists, anthropologists, and psychoanalysts. What he calls the "space of representations," we call the "imagination of space." The second, Espace perçu or perceived space refers to spatial practice. ${ }^{28}$ Like all other social practices, spatial practice is "lived" before it is conceived and theorized. ${ }^{29}$ Lefebvre ascribes to both actors and groups of actors "a certain competence as well as a particular performance." 30 They are competent in dealing with space, which is fully available to them and which they inhabit and design in a variety of ways. These actors shape the space through their actions and thus actively perform the space that surrounds them. Perceived space corresponds to what we call "spatial experience," made up of physical, social, and behavioral structures. It is incorporated in formal and informal institutions and in conscious and unconscious practices. For Lefebvre, the third aspect of the production of space is conceived space (espace conçu). It is "the space of the scientists, the interior designers, the urbanists, and the technocrats, who "slice it up" and "put it together" again. Conceived space can also be described as territorialities that are shaped by power and knowledge. It corresponds partially to what we call the "design" or the "shaping of space." 31

We do not make Lefebvre's distinction, however, between the different social classes and their various registers of action. In other words, we do not distinguish between a lived space of the dominated and a conceived space of the dominant people. From our viewpoint, all the levels of society "imagine" and "design" or "shape" the space.

The levels of spatiality interwoven into phantom borders will be discussed in detail below. For purposes of illustration, we center on the period of upheaval following 1989. For contemporary east central and southeastern Europe, this is the most recent relevant period of structuring spatiality and new border creation.

\section{The Imagination of Space}

As discussed earlier, and already elaborated by Derek Gregory, symbolic borders contribute to the mental construction processes of geographical imaginations. ${ }^{32}$ Symbolic borders create and "dramatize" the distance and difference between what they define and what they exclude. ${ }^{33}$ Maria Todorova, for instance, shows how the historical boundaries of the Ottoman Empire 1994).

26. Henri Lefebvre, The Production of Space, trans. Donald Nicholson-Smith (Oxford,

27. Ibid., 39.

28. Ibid., 38.

29. Ibid., 34.

30. Ibid., 33.

31. Ibid., 38.

32. Derek Gregory, Geographical Imaginations (Cambridge, Mass., 1994).

33. Edward W. Said, Orientalism (London, 1978), 55. 
since the 19th century have served to delimit and characterize the so-called "Balkan" region. After the partitioning of the Balkans into nation states, the former boundary lines defined a space of "Ottoman heritage," which was routinely stigmatized in the representations of the west. They became "rigid and unalterable civilizational fault lines." ${ }^{34}$ Numerous examples exist in which a long-obsolete political boundary is represented in the dominant discourse as a civilizing frontier. Phantom borders are frequently closely linked to the interests of the powerful. Ideas endorsed about Europe are no exception: throughout history, borders have been repeatedly exploited to separate civilization from barbarism, modernity from backwardness, wealth from poverty. But geographical imaginations are not just a product of the ruling (knowledge) elites (such as vis-à-vis the east or southeast European peripheries). They also refer to the ability of regional actors to establish a European spatial ordering from below.

Gregory's concept of geographical imagination inspired us to differentiate mental maps and put them into the context of social, cultural, and regional diversities within the relevant societies. In this way, phantom borders appear when differences are simultaneously communicated, both spatially and historically. Phantom borders may lead people to consider counterparts as the "other" whose residence formerly belonged to another state-administrative entity. We therefore pay particular attention to the phantom borders that structure the representations of space and to the way in which they delineate various collective ideas and practices.

National master narratives have systematically drawn from the vast repertoire of past borders to construct identity, legitimize or invalidate new boundary lines, or to show superiority. Likewise, communities such as regional, linguistic, or religious minorities can use images and symbols of phantom borders to locate themselves in space and to give their experience, situation, practice, or recognition claims meaning and congruity. These phantom borders are often considered to be familiar and taken for granted in their connection to a spatial or historical fact. The phantom border can then be made "natural" by manifold narratives. Thus, local identity is created by seemingly self-evident borders, which are not imposed by simple discourse, but reproduced by practices "from below."

Our definition of imagined space differs here from the discursive perspective of postcolonial studies. Phantom borders are not exclusively political or intellectual contrivances, deliberately created for ideological purposes to serve identity or hegemonic constructs. The concept of phantom borders obtains its specific heuristic character when it is also considered in linguistic practice and in terms of its implicit use by local actors. Specific regional and local narratives are anchored in representations, in which language or stereotypes are often passed on without reflection. On the example of the persistent inner-German border seen in social practices in the reunified Federal Republic, Antje Schlottmann has convincingly shown that the division is 
socially conditioned and reproduced in language..$^{35}$ The use of spatial concepts for referring to "here" and "over there" is sufficient for lending substance to two regional social realities-the west and the east-which are perceived and practiced differently. This geographical conception permeates everyday language outside of any discursive intention and helps to create a self-evident geographical reality. From this perspective, geographical imaginations appear intertwined with collective and individual experiences, and phantom borders are inscribed into the density of discursive practices without ideological charge. Unlike studies on mental mapping, which primarily focus on the analysis of hegemonic discourses, we understand the production and reproduction of geographical imaginations as a broader social and societal process which can occur in its own specific way, albeit at different levels. Hans-Dietrich Schultz, who provides a particularly enlightening analysis in this context, succinctly observes that borders function "as a spatial storage of meaning [räumliche Sinndeponie] for social processes." 36

The example of the postsocialist period is illustrative in this regard. For decades, until the fall of the Iron Curtain, the socialist countries of the European "East" were very closely aligned in a variety of ways: politically, economically, militarily, and culturally. They were often imagined-both internally and externally-to be a socialist-systemic unity. In retrospect, however, the political upheaval set into motion after 1989 put these notions of a shared socialist identity of the societies of east central and southeastern Europe severely into question. It is striking that in the design and justification of the new spatial positionings, the idea of a "return" to a reality before the socialist takeover played a prominent role in almost all these countries. In the Czechoslovak context, Václav Havel coined the phrase a "return to Europe," a notion which (in one form or another) had passionate advocates in most other former socialist countries. In this context, the reference to supposedly "fairer" conditions, or ones with more national freedom, became part of the incipient historicist sense-making process aimed at creating a new order, or recreating an old one, after the end of socialism.

In this context, the slogan of a desired "return to Europe" became a hallmark of the early 1990s. In his famous article from 1984, Milan Kundera even interpreted central Europe as a "kidnapped" part of the west, thus advancing an emotional, if scientifically dubious, concept.

Considering what it could imply at a regional level, the western and northern parts of postwar Poland and the Czech lands convincingly demonstrate the link between the truly contemporary purposes of spatial imagination, on the one hand, and the given repertoire defined by historical experiences, on the other. Here, the proximity to Germany, one of the major countries of western Europe, contributed to a new spatial design that undercut the transnational heritage at a regional level, despite increased tourism and intensifying cultural

35. Antje Schlottmann, RaumSprache: Ost-West-Differenzen in der Berichterstattung zur deutschen Einheit: Eine sozialgeographische Theorie (Stuttgart, 2005).

36. Hans Dietrich Schultz, "Natürliche Grenzenals politisches Programm," in Claudia Honegger, Stefan Hradil and Franz Traxler, eds., Grenzenlose Gesellschaft? (Wiesbaden, 1999), 328-43. 
and economic exchange. An important benchmark was the "open regionalism" advocated by the historian Robert Traba and the writer Kazimierz Brakoniecki, the founders of the Cultural Association Borussia in Olsztyn in the former eastern Prussia in 1990. Whether Gdańsk or Szczecin, Wrocław or Gorzów Wielkopolski, cultural initiatives by officials or other local actors highlighted the reciprocal links between a spatial imagination bolstered by history and the material (re)shaping of regional and local identities through new cultural infrastructures dedicated to special chapters in history. To paraphrase French sociologist Marie-Claire Lavabre, never would the "weight" of the past (le poids du passé) completely determine the "choices" of the pasts (le choix du passé). ${ }^{37}$

All these spaces, therefore, cannot be seen as "uniformly" conceived or "naturally" oriented by a geographical destiny or identified in any one of the societies under consideration. The debates over historical spaces were in essence a political competition, in which imagination was used to establish a putative link to the west and to bridge regional identities and capitals, but also between different regions. These different interpretations were the cause of increasing tensions in the public discourse regarding the understanding of historical spatial relations, yet they must be examined in all their breadth. ${ }^{38}$

The recourse to presocialist space was partially associated with ideas about what was considered the legitimate expansion of the state or the nation. For instance, it became popular again in Hungary to refer back to the "historical Kingdom of Hungary" and the borders of Hungary before the "catastrophe of Trianon," that is before the peace treaties after the First World War. ${ }^{39}$ While anyone could condone taking recourse to presocialist governmental spaces in a democratizing society, it nevertheless inflamed controversies-partly in relation to the spatial design of the states.

In the course of establishing new/old demarcations in the democratizing societies of central and southeastern Europe post-1989, regional differences and developmental disparities were also topics of political debate. Historical or cultural reasons were often cited as justifications for the regional differences. In the case of Slovakia in the early 1990s, for instance, the deteriorating economic situation of the Slovak regions within the Czech and Slovak Federative Republic (ČSFR)-renamed in 1990 following the Czechoslovak Socialist Republic (ČSSR) - was widely and vociferously decried by the Slovak elite. ${ }^{40}$ But demarcation discourses were conducted in many other countries and also included internal borders, which were often former political boundaries.

37. Marie-Claire Lavabre, Le fil rouge: Sociologie de la mémoire communiste (Paris, 1994), 31.

38. On the different discourses and their emotionalization, see e.g. Maruška Svašek, Postsocialism: Politics and Emotions in Central and Eastern Europe (New York, 2006).

39. Wolfgang Aschauer, "Ceci n’est pas la Hongrie-Grenzen in Realität und Imagination am Beispiel Ungarns," (paper presented at the symposium of the scientific committee of the Southeast Europe Association on the topic "Südosteuropa und die alten/neuen Grenzen. Ein analytischer Blick zurück im Jahr 25 nach der Wende,” Berlin, February 28, 2014).

40. Gil Eyal, The Origins of Postcommunist Elites: From Prague Spring to the Breakup of Czechoslovakia (Minneapolis, 2003). 


\section{Spatial Experience}

From another perspective, we want to reflect more systematically on the continuity and change in the historic "experience" of space, thus moving beyond the discursively-produced or imagined space referred to above. Following Reinhart Koselleck, we understand experience as simultaneously individual and intersubjective. At the level of the individual, the concern is with a past which has been made present and mobilized in action. At the intersubjective level, experience is stored in both formal and informal control systems, which are established and gradually change over time across multiple generations. This experience can be deliberately visualized and made the subject of official commemorative politics. The experience, however, also enters unconsciously into a habitus, routine, and social morphology. ${ }^{41}$

At the same time, experience is not inherently stable or constant, but is repeatedly remeasured and redefined. Different experiences can overlap and influence each other. What is more: new hopes, disappointments, or expectations refashion the experiences of actors retroactively. The temporal structure of experience thus always also includes a retroactive expectancy.

Old/new "experiences" thus can also affect intra-societal meanings of spaces and borders. They can also undergo change at certain points in time, when for instance the fading of established meanings goes hand in hand with a "remembrance" of spatial experiences or configurations that were relevant further in the past.

The "Macedonian" transitional dynamics after the end of socialism are exemplary. The so-called "Macedonian question" has a long history dating back to the Ottoman Empire, which included the respective areas and localities for more than a half millennium. As an object of irredentist claims of several nation states that came into being in the course of the nineteenth century, the Macedonian question also played a role in Great Power competition at the end of the nineteenth and beginning of the twentieth centuries. Macedonia was also the location of one of the most important front lines in the First World War. "Macedonia" was partitioned in 1912/13 and then again in 1918. New borders were drawn and territories were allocated to Serbia/Yugoslavia, Bulgaria, Greece, and partly to the newly established Albanian state. Towards the end of Second Word War, the "Socialist Republic of Macedonia" was established within the emerging socialist Yugoslav state. The decades of Yugoslav socialism, which became increasingly peculiar in the course of the development of "self-management socialism," shaped the societal experiences of several generations in this first instance of modern Macedonian "statehood" within Yugoslavia. The Macedonian variant of socialism differed markedly from the one in neighboring socialist Albania and Bulgaria. Compared with the Hoxhaist system in Albania (which was initially oriented toward the USSR, then communist China, and finally took on a posture of self-imposed isolation) or Bulgarian

41. Reinhart Koselleck, Futures Past: On the Semantics of Historical Time (New York, 2004), 259. 
socialism (which was heavily tilted toward the Soviet Union), the features of this Yugoslav variant of socialism were unique. There were also stark contrasts with its southern neighbor Greece, which eventually established a western- oriented and anticommunist social system after WWII and the Greek Civil War from 1946-49.

These specific developments shaped the societal as well as the spatial routines of the inhabitants of Yugoslav Macedonia. The reestablished borders soon appeared permanent, as the Cold War order materialized and was regarded as final. Moreover, the experience of a specific, local variant of a MacedonianYugoslav social development made the experience of a Macedonian self-management order a characteristic feature of social life, and the existing border increasingly meaningful to neighboring states and regions. ${ }^{42}$

But in the beginning of the 1990s, as the Cold War order collapsed, dissolving Yugoslav self-management socialism started an unforeseen and dramatic period of change. In the course of the war-torn dissolution of Yugoslavia, its socialist model lost its former significance and in 1991 the "Former Yugoslav Republic Macedonia" became an independent state. In this period of upheaval, the everyday life of Macedonian inhabitants suddenly became increasingly similar to the lives of the inhabitant of postsocialist Bulgaria and Albania: there was now a common, cross-border experience of the definite collapse of the state-controlled, corporatist economy as well as massive de-industrialization. This transformation, triggered by the introduction of capitalist models, dominated the experience of large parts of the societies in the three postsocialist countries (Macedonia, Bulgaria, Albania) and "harmonized" their experiences, contrasting them with those in Greece, where socialism was never introduced and the market economy shaped its post-war history. ${ }^{43}$

The significance of earlier societal and regime experiences under socialism faded rapidly. References to "original," "natural," or "imagined" social as well as spatial settings of the presocialist or even Ottoman past subsequently gained new importance. Such references also entered discourses regarding the "legitimacy" of existing borders. This can be seen, for example, by the Macedonian-Albanian area around Lake Ohrid, highlighting the significance of regionality and locality. This border territory was marginalized during socialism, but obtained a new meaning as a "traditional historical region" when border controls were loosened (and temporarily also totally collapsed) in the course of the 1990s. New references to the past would also become

42. Paul Shoup, Communism and the Yugoslav National Question (New York, 1968); Irena Stefoska, "Nation, Education and Historiographic Narratives: The Case of the Socialist Republic of Macedonia (1944-1990)," in Ulf Brunnbauer and Hannes Grandits, eds., The Ambiguous Nation: Case Studies from Southeastern Europe in the 20th Century (Munich, 2013), 195-229.

43. Keith S. Brown, "Political Realities and Cultural Specificities in Contemporary Macedonian Jokes," Western Folklore 54, no. 3 (1995): 197-212; Loring M. Danforth, The Macedonian Conflict: Ethnic Nationalism in a Transnational World (Princeton, 1995); Jane Cowan, Macedonia: The Politics of Identity and Difference (London, 2000); Žarko Trajanoski, “National' Flags in the Republic of Macedonia,” in Brunnbauer and Grandits, eds., Ambiguous Nation, 449-77. 
an important aspect of a wider, "national" level in Macedonia. Aspirations of some nationalists in Macedonia (and partly in Bulgaria) and the widespread fear of many politicians in Greece about the "return" of an "undivided Macedonia" of the past entered regional politics starting in the 1990s and have not disappeared through the present. ${ }^{44}$

\section{Shaping of Space}

Phantom borders are not only imagined and experienced, but are also active themselves in shaping space. Following urban sociologist Martina Löw, we view space as a "relational ordering of social goods and people." ${ }^{\text {"5 }}$ Löw refers to two dimensions in the constitution of space. First, she emphasizes the processual or behavioral dimension. Second, she points out that space structures action. From this perspective, phantom borders are not to be understood as stable realities that precede social processes but as an active part of them. They are thus at once an active and passive part of the relationally perceived space. ${ }^{46}$

With this third dimension of the phantom borders concept, we want to highlight how the specific production of space interrelates with the production of meaning and the practices of actors. We refer to examples related to the specific property and production structures of arable land in regions like Transylvania, Vojvodina, and others that had been part of the Habsburg Empire before 1918. To create a more just and reliable taxation of land, in the course of the nineteenth century the Habsburg administration undertook the vast endeavor of geodetically measuring all land and registering all parcels in a cadaster and land register. This occurred simultaneously with the abolishment of feudal bondage. On the one hand, the establishment of a land registry in many cases only formalized the traditional use of particular parcels, which often could be traced back several hundred years partly due to the physical structure of the soil. On the other hand, the reordering of space from arable land under feudal conditions to privately owned parcels initiated the peasants' economic, social, and political upward mobility. When after the First World War, the post-Habsburg nation states decided to discontinue the institution of the land registry, some of the professionals (geodesists, cadaster and land register officials, public notaries) and peasants defended the Habsburg Rechtsstaat and its ability to shield the local actors from interferences by economically and/or politically more powerful actors. The example of the

44. Robert Pichler, "Makedonische Albaner im Spannungsfeld von Nationsbildung und islamischer Erneuerung," in Christian VoßandJordanka Telbizova-Sack, eds., Islam und Muslime in (Südost)Europa im Kontext von Transformation und EU-Erweiterung (Munich, 2010), 195-222.

45. Martina Löw, Raumsoziologie (Frankfurt/Main, 2001), 224.

46. Martina Löw's relational conception of space builds on the dualistic conception of structure in Anthony Giddens, The Constitution of Society: Outline of the Theory of Structuration (Cambridge, Eng., 1984). A similar concept is also found in French geography, see Augustin Berque, "Paysage-empreinte, paysage-matrice: éléments de problématique pour une géographie culturelle,” Espace géographique 13, no.1 (1984):33-34; and Lefebvre, The Production of Space, 37. 
Habsburg system of land ownership and its afterlife in post-Habsburg nationstates illustrates how the three spatial dimensions can be articulated in a way that allows for a better understanding of historical continuities and ruptures. Human agency had shaped and reordered space, and now the expectations for legal security, economic progress, and political autonomy tied to this spatial order was shaping human agency. ${ }^{47}$

The same dynamic can be observed after 1989. A cultural and sometimes political regionalism focused on specific regions as being allegedly more "central European" than others, due to their Habsburg traditions. Some allegedly dispositive values are centered on a specific economic ethos like honesty in business, industriousness, and punctuality. As a result, the perception and claim that a sub-region like Transylvania belongs to a meso-region like central Europe is shaped to some degree by a particular property culture. At the same time, this perception shapes what citizens can legitimately expect from the state. It is no coincidence that Klaus Iohannis, the former mayor of the Transylvanian city of Sibiu, ran a successful campaign for the Romanian presidency in 2014 on a carefully-crafted post-Habsburg agenda encompassing the aforementioned values with the slogan "Romania-a country of things well done."

On a more immediate level, the presence or absence of reliable data concerning land ownership considerably influenced the process of decollectivization in Romania and other countries in the region..$^{48}$ In Transylvania, a Habsburg document was considered the best proof for ownership, so many families who had held on to these documents during communist times were easily able to obtain the exact parcel that was dispossessed through collectivization. With no such documents available in Moldavia and Wallachia, retrocession was easier questionable and took longer. In the postsocialist period this regional difference between land institutions had a direct impact on the actors' scopes of action..$^{49}$ Conceptualizing space as fundamentally dynamic finally points to the interconnectedness of space and time-one of the most pervasive concerns in historiography and the humanities in general. Human agency shapes space over time and imbues it with meaning in such a way that space, in turn, shapes the perception of both the past and the imagined future.

\section{Phantom Space as Actualization of the Past and the Imagined Future}

The three analytical levels of phantom borders described so far for purposes of illustration must be linked together. The "experience" of space carries particular weight, because it constitutes a contingent element in the historical

47. Dietmar Müller, "Eigentum verwalten in Rumänien. Advokaten, Geodäten und Notare (1830-1940)," in Dietmar Müller and Hannes Siegrist, eds., Professionen, Eigentum und Staat. Europäische Entwicklungen im Vergleich (19. und 20. Jahrhundert) (Göttingen, 2014), 75-132.

48. Katherine Verdery, The Vanishing Hectare: Property and Value in Postsocialist Transylvania (Ithaca, 2003).

49. Béatrice von Hirschhausen, Les nouvelles campagnes Roumaines: Paradoxes d'un "retour« paysan (Paris, 1997); Violette Rey, ed., Les nouvelles campagnes de l'Europe centre orientale (Paris, 1998). 
process. On the one hand, experience is spatially and historically conditioned; on the other, the actors situate their experience in historically-variable geographical imaginations, resulting in various interpretations and actualizations. The phenomena that are described at the three levels inevitably change over time. In conditions of social upheaval, internalized, spatially-reproduced and seemingly stable routines, experiences, or endowments of meaning can quickly be completely reviewed. New phantom borders and spaces can consequently appear, while others disappear.

At this point of our argument, we can now offer a more concise definition of the concept of phantom borders, or phantom spaces: they designate the performativity of previously-existing historical territories. Former historical territories have the capacity to shape both the experience and the imagination of a social group and, consequently, to establish regional patterns in a specific domain. This capacity is not permanent but limited to specific historical moments. Phantom borders and phantom spaces appear and disappear depending on the historical and geopolitical circumstances.

The concept of "phantom borders/phantom space" contrasts with the existing research on the geo-cultural longue durée. The latter focuses on the historical legacy and cumulative and systemic processes that keep actors on historical paths that have been predetermined by long-established social relations, structures, and institutions. ${ }^{50}$ This line of questioning insists on the historical causation of long-term processes.$^{51}$ However, by focusing on historical "path dependence," it effectively marginalizes the actors and ignores their agency. The concept of "phantom spaces" offers an alternative perspective, which entails three main aspects.

First, the concept of "phantom borders/phantom space" focuses on the experience of the actors and not on the regions. In fact, it considers regional differences to be a product of the everyday behavior of people. The institutional, social, and structural heritage is not considered to be exogenous, but rather a creation "from below." It is thus to be viewed from the specific perspective of the actors, for instance, in terms of their embeddedness in daily life and social memory. Past periods do not constitute a continuum or "causal chain," as described by Paul Pierson. ${ }^{52}$ Instead, the past is permanently updated by local actors in a selective way and represents a set of referenced resources. Depending on their momentary perception at any point in time,

50. Among the works on path dependency we may refer to Paul Pierson, "Increasing Returns, Path Dependence, and the Study of Politics," The American Political Science Review 94, no. 2 (Jun 2000): 251-67; Ian Greener, "The Potential of Path Dependence in Political Studies,” Politics 25, no. 1 (2005 ): 62-72; Keith Darden and Anna Grzymala-Busse, "The Great Divide: Literacy, Nationalism, and the Communist Collapse," World Politics 59, no. 1 (Oct. 2006): 83-115; Sascha O. Becker et al., "The Empire is Dead, Long Live the Empire! Long-Run Persistence of Trust and Corruption in the Bureaucracy," The Economic Journal 126, no. 590 (February 2016): 40-74; Leonid Peisakhin, "Cultural Legacies: Persistence and Transmission," in Norman Schofield and Gonzalo Caballero, eds., The Political Economy of Governance: Institutions, Political Performance and Elections (Cham, 2015), 21-39.

51. Paul Pierson, Politics in Time: History, Institutions, and Social Analysis (Princeton, 2004), 79-102.

52. Pierson, 79. 
these local actors can make use of and reproduce the heritage of the past, or ignore or even disqualify it.

Second, our approach opens up an interpretation of cultural spaces that entertain new visions of the future and of joint beliefs. The actors use their resources with respect to the past, but also with respect to the horizon of future expectations. They engender their own perception of the world, which takes shape between a certain experience that is "full of past reality," and an expectation of an imagined future..$^{53}$

Third, our analysis of phantom spaces indicates that visions of the future are not only endogenous. In other words, to a certain degree they emerge naturally from historic path dependencies, as experienced by local communities and their shared past. These local visions of the future are also influenced by mental maps originating from higher levels of power. Hegemonic knowledge defines, among other things, the "center" and "periphery," as well as "modern" and "archaic" regions. It accordingly prescribes geographies of the future to the local societies, which more or less freely internalize them. The local populations thus identify potential developmental spaces and define their future horizons in terms of the borders implicitly defined by the mental maps. These mental maps and their implied narratives of the past, and visions of the future, can be highly "efficient" because they are considered to be natural and self-evident by the local actors.

\section{Outlook: A Contribution to the Discussion on Area Studies}

In this paper, we have defined the concept of "phantom borders" and described its heuristic potential. It allows us to understand cultural areas as unstable and hybrid constructions, extending between embodiment and social fantasy, rather than as frozen legacies or pure imaginations. The topic is relevant not only for east European studies, but also for research in "new area studies" in general. In fact, our focus on phantom borders in eastern Europe was inspired by a profound concern about the present and future of area studies. ${ }^{54}$ Since 1989, cultural and social-scientific research on eastern Europe has faced a two-fold challenge. The end of the bloc's isolation and the ever-increasing impact of globalization on the topics and methods of cultural and social sciences had lasting effects on the self-understanding of regional research on eastern Europe. Moreover, its status was fundamentally questioned, especially in the years after 1989. At the same time, regional research on eastern Europe has maintained a strong foothold, above all in the former

53. Koselleck, Futures Past, 255-75.

54. On the origin of area studies in the context of the Cold War, see David L. Szanton, ed., The Politics of Knowledge: Area Studies and the Disciplines (Berkeley, 2004); David C. Engerman, Know Your Enemy: The Rise and Fall of America's Soviet Experts (Oxford, 2009). Recent research historicizes the close linkage between area studies and non-scientific interests as part of a scholarly history of the Cold War. See Mark Soloveyand Hamilton Cravens, eds., Cold War Social Science: Knowledge Production, Liberal Democracy, and Human Nature (New York, 2012); Paul Erickson, Judy L. Klein, Lorraine Daston, Rebecca Lemov, Thomas Sturm and Michael D. Gordin, How Reason Almost Lost Its Mind: The Strange Career of Cold War Rationality (Chicago, 2013). 
"frontline states" of the Cold War. It also has considerable potential to support the redefinition of the position of cultural and social sciences above and beyond any national narrowing or Eurocentrism. ${ }^{55}$ In contrast to "general history" (which has arguably been equally affected by the two outlined developments), regional research has undergone a process of critical introspection.

It is worth recalling the interdisciplinary controversy surrounding east European studies that took place in the late 1990s in German-speaking countries, especially in the journal Osteuropa. Thought-provoking discussions of spaces and borders were already put forward at that time regarding the criticism of a regional science that makes use of an unreflective concept of space. Responding to Jörg Baberowski's diagnosis that the assertion of a distinct geographical area implies no "scientifically defensible separation of scientific subjects," representatives of non-Russian and non-Soviet related subdisciplines emphasized the importance of spatial organization and the historical variability of spatial allocations, which raised relevant overarching historiographical issues. ${ }^{56}$ Mathias Niendorf, for instance, in reference to the territories of Poland and Lithuania and their diverse inner-regional divisions, has stressed that east European studies should be more "than a summation of national historiographies." 57 Stefan Troebst has linked the analytical categories of space and time in observing that "the map of Eastern Europe and Europe as a whole still resembles a palimpsest, that is, a medieval parchment manuscript, whose original text has been removed and replaced by another." 58 The critical examination of the specific region of eastern Europe has given rise to a new perspective that addresses a general concern within area studies. Specifically, the latter should be more than merely a testing ground for theories of "general" disciplines. Instead, area studies needs to be able to formulate its own research-guiding hypotheses, which, in turn, have an innovative impact on the research practices in the cultural and social sciences. ${ }^{59}$

The increasing relevance of non-European regions in the cultural and social sciences post-1989 has been another challenge. This period was certainly an opportunity for regional studies on eastern Europe to promote itself. What is more, the knowledge that area studies produce has become all the more valuable given the increasing recognition that globalization cannot be

55. See the essays in Zeit im Spiegel: Das Jahrhundert der Osteuropaforschung, special issue of Osteuropa 63, no. 2-3 (2013), esp. Stefan Troebst, "Sonderweg zur Geschichtsregion: Die Teildisziplin Osteuropäische Geschichte”: 55-80.

56. Jörg Baberowski, "Das Ende der osteuropäischen Geschichte: Bemerkungen zur Lage einer geschichtswissenschaftlichen Disziplin," in Stefan Creuzberger et al., eds., Wohin steuert die Osteuropaforschung: Eine Diskussion (Cologne, 2000), 42.

57. Mathias Niendorf, "Mehr als eine Addition von Nationalhistoriographien. Chancen der Osteuropäischen Geschichte als Regionalwissenschaft," in Stefan Creuzberger et al., 101-6.

58. Stefan Troebst, "Ende oder Wende? Historische Osteuropaforschung in Deutschland: Vier Anmerkungen zu Jörg Baberowski,” in Stefan Creuzberger et al., 63.

59. This was the criticism that was already made in the early 1990 s about east European Studies, see Stefan Creuzberger et al, "Osteuropaforschung im Umbruch: Motive, Hintergründe und Verlauf einer Fachdebatte in Deutschland,” in Stefan Creuzberger et al., 15. 
described as an extension of "European" or "Western" paradigms to the world at large, but is rather a history of exchange and interdependency. If we are to take this view of entanglement seriously, then it is no longer appropriate for regional studies to have a "subservient function" in merely confirming or refuting "general" theories on the basis of illustrative material. ${ }^{60}$ So-called general disciplines in fact develop their theories in reference to "tangible" regional objects, while area studies are unquestionably involved in theory formation. For east European studies, this means that there are at once threats and opportunities. On the one hand, the studied regions are still looked at through the prism of the Cold War or the prism of "backwardness" vis-à-vis a loosely-defined European "center." On the other hand, "Eastern Europe" demands to be addressed as a region in terms of its exchanges and interactions to "Europe" and, of course, to the "world." As a consequence, this further entails deconstructing a quasi-universal point of view. Last but not least, the study of eastern Europe tests the second major interpretational framework that has shaped and continues to shape the view on historical regions.

To what extent was eastern Europe a region formed by asymmetrical power relations? A region where colonial and imperial structures were historically significant? A region that was organized by diverse forms of micro and internal colonialism? And, finally, a region where the linkages of knowledge and power relations were particularly central due to its proximity and belonging to Europe? Given the relevance of these issues for a critical reflection of area studies and contemporary global history, new approaches to the region need to be exploited that help position east European studies within a dynamically-evolving field of research. We hope that the concept of phantom borders will make a contribution to this effort.

60. Birgit Schäbler, "Einleitung. Das Studium der Weltregionen (Area Studies) zwischen Fachdisziplinen und der Öffnung zum Globalen: Eine wissenschaftsgeschichtliche Annäherung," in Birgit Schäbler, ed., Area Studies und die Welt: Weltregionen und die neue Globalgeschichte (Vienna, 2007), 11-44. 